UDC 78.072.2

\section{Цитування:}

Горовой С. Г., Пісаренко Ю. В., Іщенко О. Є. Взаємодія інтерпретації та імпровізації у джазовому вокальному виконавстві. Вісник Національної академії керівних кадрів культури і мистеитв : наук. журнал. 2021. № 2. С. 223228.

Gorovoy S., Pisarenko Ju., Ishchenko O. (2021). Interaction of Interpretation and Improvisation in Jazz Vocal Performance. National Academy of Culture and Arts Management Herald: Science journal, 2, 223-228 [in Ukrainian].

\author{
Gorovoy Sergiy, \\ Candidate of Art, Professor, \\ Head of the Department «Orchestra Instruments» \\ of the Dnipropetrovsk Music Academy by M. Glinka \\ ORCID: https://orcid.org/0000-0002-3463-0372 \\ gortrom2@ukr.net \\ Pisarenko Julia, \\ Senior Lecturer of the \\ Dnipropetrovsk Music Academy by M. Glinka \\ ORCID: https://orcid.org/0000-0002-3545-1958 \\ jazz.julia16@gmail.com \\ Ishchenko Olga, \\ Lecturer of the \\ Dnipropetrovsk Music Academy by M. Glinka \\ ORCID: https://orcid.org/0000-0002-8904-0521 \\ Olya.ischenko@gmail.com
}

\title{
INTERACTION OF INTERPRETATION AND IMPROVISATION IN JAZZ VOCAL PERFORMANCE
}

The purpose of the article is to explore the various interpretations of the concepts of "improvisation" and "interpretation" encountered in modern science, to identify the most appropriate definitions of these concepts that reveal the specificity of jazz performance and determine the relationship of these two concepts. The methodology of the article is the researches of improvisation and interpretation of various orientations. First, a scientific approach is used, which characterizes this process as a creative method. The scientific works devoted directly to improvisation in jazz are also used, which contain analysis of the improvisations of well-known performers and exercises for teaching local techniques. The scientific novelty of the work is that the term "interpretation" is considered in a broader sense in interaction with improvisation, that is, not only as an interpretation of other people's musical ideas in performing activities but also as an interpretation of personal artistic intentions in the process of musicians' activity. Conclusions. The interaction of interpretation and improvisation is clearly traced, since interpretation is an aspect of musical practice that proceeds from the differences between the recorded music notation and the live performance of the work. Consequently, this process inherent element of unpredictability. The interrelation of the interpretation of the musical text and the mastery of the improvisatory demonstration of this text by the interpreter, which is determined by his individual qualities, is traced.

Key words: jazz, jazz vocals, jazz performance, improvisation, interpretation.

Горовой Сергій Гаврилович, кандидат мистеитвознавства,професор, завідувач кафедри «Оркестрові інструменти» Дніпропетровської академії музики їм. М. Глінки; Пісаренко Юлія Василівна, старший викладач Дніпропетровської академї музики їм. М. Глінки; Іиценко Ольга Свгенівна, викладач Дніпропетровської академії музики їм. М. Глінки

Взасмодія інтерпретації та імпровізації у джазовому вокальному виконавстві

Мета статті - дослідити різні трактування понять «імпровізація» та «інтерпретація», що зустрічаються у сучасній науці, виявити найбільш відповідні визначення цих понять, які розкривають специфіку джазового виконавства і визначити взаємозв'язок цих двох понять. Методологічною основою статті виступають дослідження імпровізації та інтерпретації різної спрямованості. Використовується науковий підхід, який характеризує цей процес як творчий метод. Так само використовуються наукові роботи, присвячені безпосередньо імпровізації у джазі, які містять аналіз імпровізацій відомих виконавців та вправи для навчання локальним технічним прийомам. Наукова новизна роботи полягає у тому, що термін «інтерпретація» розглядається в більш широкому значенні, у взаємодії з імпровізацією, тобто не тільки як трактування сторонніх музичних ідей у виконавській діяльності, але й як тлумачення особистих художніх задумів у процесі діяльності музикантів. Висновки. Чітко простежується взаємодія інтерпретації та імпровізації, оскільки інтерпретація є аспектом музичної практики, який виходить з відмінностей між зафіксованим нотним текстом $\mathrm{i}$ живим виконанням твору. Отже, цьому процесу властивий елемент непередбачуваності. Простежується

CGorovoy S., 2021

CPisarenko Ju., 2021

(CIshchenko O., 2021 
взаємозв'язок тлумачення нотного тексту і майстерності импровизаторскої демонстріраціі цього тексту виконавцем - інтерпретатором, яке визначається його індивідуальними якостями.

Ключові слова: джаз, джазовий вокал, джазове виконавство, імпровізація, інтерпретація.

Relevance of the research topic. The wide development of musical culture determined an important place occupied by performing in contemporary social life, its great importance as an artistic and ethical force affecting the spiritual world of man. Hence the increased interest in questions of performance and scientific problems in this area.

In modern culture, jazz performance implies the concept of interpretation in close connection with the concept of improvisation. The problem of the interaction of improvisation and interpretation in jazz vocals has been studied little - most of the research is mainly devoted to instrumentalists. There is a need to consider improvisation and interpretation not in opposition, but in interrelation with each other.

The aim of the article is to explore the various interpretations of the concepts of "improvisation" and "interpretation" encountered in modern science, to identify the most appropriate definitions of these concepts that reveal the specificity of jazz performance and determine the relationship of these two concepts.

The scientific novelty of the work is that the term "interpretation" is considered in a broader sense in interaction with improvisation, that is, not only as an interpretation of other people's musical ideas in performing activities but also as an interpretation of personal artistic intentions in the process of musicians' activity.

Improvisations are devoted to studies of a different direction - works that characterize it as a creative method (K. Dalhaus, G. Wollner, E. Ferand, Yu. Glushchenko, A. Kolosov, B. Saifullaev, A. Tolshchin, E. Shpakovskaya, etc.). Works devoted directly to improvisation in jazz, in most cases, are educational and practical manuals (J. Cooker, R. Riker, I. Bril, A. Molotkov, A. Rogachev, Yu. Chugunov, etc.) and mainly contain an analysis of improvisations known performers, exercises for teaching local techniques.

Each epoch understands, reveals, and executes great works of art differently: the generation of people, past a new historical path and enriched by historical experience, finds something new in the great creations of the past. "Like all living things, performing art can not move forward without updating itself" $[4,206]$. "Interpretation (Latin interpretatio "clarification","interpretation") is an aspect of musical practice that results from the difference between the noted music fixed once and for all and we live with a performance that always has an element of unpredictability" [6].

The art of interpretation in the proper sense of the word arises in the middle of the XVIII century when the musical composition and performance gain more independence, and the performer becomes an interpreter of not their own works, but works of other authors. Until the beginning of the 19th century, the interpretation of the music text was in fact not separated from the composer's work (the composers either performed their own music or controlled its performance).

In the era of Romanticism, the type of musician-interpreter interpreting other people's music from the standpoint of his individuality was established. This is no longer a craftsman, but a universal artist, for whom the artist and the musician are merged in one person - creative improvisation is the basis of his performing skills.

With the advent of the XIX century, various styles of musical performance develop, there are associated psychological, ideological, and technological problems of performance. The study of the interpretation of the artists of the XIX century is facilitated by a closer continuity of the executive schools, as well as by the availability of editorial offices, processing, and transcriptions of musical works.

Assistance in the study of the art of the interpretation of the twentieth century has a sound recording that has preserved many examples of interpretations of outstanding performers of the past - the art of interpretation receives more and more reflection in sound recordings every year.

For the study of jazz performance as an interaction of interpretation and improvisation of a variety of performer, we suggest considering the meaning of these two terms in the theoretical aspect and exploring how elements of improvisation and interpretation interact in jazz vocals.

In musical encyclopedias, the following notation of terms is given. "Interpretation (Latin interpretatio, clarification, interpretation) artistic interpretation of the singer, instrumentalist, conductor, chamber ensemble of the musical work in the process of its performance, disclosure of the ideological and figurative content of music by expressive and technical means of performing art. Interpretation depends on the aesthetic principles of the school or the direction to which the artist belongs, on his individual characteristics and 
ideological and artistic design "[8, 549-550]. "Interpretation (Latin interpretation, interpretation) the artistic disclosure of a musical work in the performance process, depending on its design and individual characteristics, the aesthetic principles of the school or the direction to which the performer refers" [14, 67-68].

Interpretation is subject to any work of art, regardless of whether it belongs to modern listeners, or the art of the past. In the process of interpretation, what has been conceived by the composer is recreated, but with the introduction of his personal relationship. Interpretation, that is, the process of interpreting a musical work, is a generalization and crystallization of aesthetic ideals, performing variants and styles of performance that are characteristic of their time, which each time pass through the individual consciousness of the performer. In it, the role of the psychological attitude toward observing the details of the author's text and the subjective attitude towards it is important. There are two types of interpretation: objective (the will of the author dominates) and subjective (for the performer are important and their own thoughts and feelings).

The problem of objective and subjective interpretation arose because of opposing psychological attitudes: the intellect (the emotional storehouse of the performer), the psychological climate, the specifics and level of development of culture. Interpretation involves the combination of the artist's personal creative freedom, and the execution of the composer's intention, fixed in musical notation. In the interpretation of the important role of life and music associations.

Each significant performance of a great musician makes his own corrections (changes) in the work created by the composer. Especially they are noticeable if the composition and performance of the work diverge in time, and its interpretation can differ significantly from different performers, presenting many variations of the sound of this musical work. Thanks to the flow of time, each new performance of the same artist will also be somewhat modified. «A truly effective performance, as it were, takes in two points: the time that is reflected in the musical work and the time in which the interpreter lives» [4, 206].

To the music created by the composer became the property of listeners, a performer with abilities, skill, and ability to feel, to comprehend the reality embodied in musical images is necessary. A musician, performing a musical work, necessarily reflects the spirit and tastes of the time, the social environment. The role of an improviser in terms of creativity of the creative process is certainly very broad and effective.

At its core, the interpretation is static, its necessity lies in the language itself (including and artistic), as a means of communication. The means of conveying the idea is a system of signs that appear in the form of any material expression - word, picture, sound, etc. Each sign has many meanings, therefore, interpretation is a natural component of any form of human communication.

We see that the interpretation is, first, explanation and interpretation of any note text (recorded in a musical notation or deciphered from the audio by the performer himself, which is more common among jazz performers than academic ones). "Interpretation requires a certain system of views on musical phenomena, on art in general and on performing art in particular" [1, $105]$.

In our opinion, it is advisable to consider the concept of "artistic performing interpretation" not only as an interpretation by a performer of a composer's musical text, but also as an interpretation by the improviser of his own creative ideas and original musical material, which is the beginning of the improvisation process. The real process of improvisation is based on performing activity, which has the same nature in all situations, connected with the reconstruction of musical speech through instrumental (or vocal) possibilities. The very fact of execution is carried out by similar logically mediated actions aimed at sounding the written composer's text or for the instant intonational realization of the internal auditory intentions of the improvisator. Therefore, we attribute improvisation to the field of performance. "Improvisation is a complex phenomenon, the scientific interpretation of which has been quite controversial at all times" [3, 252].

From the history of musical art, it is known that improvisation is the primary and the most ancient kind of creativity. "Musical improvisation is historically older than written composition" [13, $3]$. It is present in the daily life of man, art, game sports, politics. "Improvisation has always been the basis of folk art, and it continued to exist even in the most complex forms of composition (instrumental concert, opera) until the XIX century when the composer was finally separated from the performers" [3, 252].

The very word "improvisation" in the everyday life of European musicians appeared in the critical period of single combat of improvisational and written principles. Improvisation in scientific literature, encyclopedic publications is defined as a form of the creative 
act, directly, in the process of which a work of art is created. For example, in painting, these are crocs - sketches of drawing from nature, expressing the primary thought, primary impressions. In the musical art, "improvisation (Latin Improvisus - sudden, unexpected) composing music without preliminary preparation (impromptu) [14, 66]. The dictionary of musical terms gives one more definition: «improvisation» is a musical work in free form. Describing the nature and structural features of improvisation, B. Asafiev wrote: “... In its historical discovery, improvisation is the simultaneous combination of two creative abilities, the composition of music in the process of its execution (...). This creativity, which does not follow the predefined formal schemes and connects the visible freedom of exposition («freedom from schemes») with surprise in comparing ideas ..." [2, 49-50].

Improvisation as a special kind of spontaneous creative activity belongs to the distinctive properties of jazz. This is what separates jazz performance from other kinds and varieties of musical performing practice. Improvisation promotes increased expression of performance, the establishment of interactive contacts between musicians and listeners. Improvisation demonstrates not the result, but the process of creating music, which gives a special appeal to the performances of jazz musicians [12, 48].

If the performer interprets other people's artistic ideas coded in the music material, demonstrating their attitude towards them and thereby revealing the composer's intent and his own creative individuality, the improvisator directly interprets himself. In essence, these artistic actions differ only in the nature of work and in the specificity of creative talent, having a similarity in the context of performance as a spiritualized and intellectual process of extracting sounds. At the same time, the measure of interpretation (as a factor of subjective expression of will) is much higher precisely in improvisational work. Since professional improvisational art refers to artistic forms of creativity, improvisation, in fact, is an artist performing activity that potentially possesses functional signs of interpretation.

In matters of interpretation, exceptional value belongs to the imagination-the mental process of folding the image of future activity or a concrete representation of the final product result. As for the interpretation in jazz, here the jazz performance of a song or jazz standard implies a certain jazz style: the ability to sing in a swing, to imitate instrumental sound, the possession of a peculiar melismatic, methods of extracting sounds, scat technique, etc. Jazz performers try to approach maximum individualization, the peculiarity of the performance of the interpreted musical text. Here more freedom is allowed, unlike interpretation in classical music. In the development of jazz music, vocalists often imitated instrumentalists in their oeuvre and this affected the vocals of jazz singers. The vocals became more instrumental, which was clearly manifested in the manner of "scat singing", for example.

Every musician who makes attempts to improvise knows that the art of improvisation is the highest musical task that requires the presence of musical talent. In jazz, instead of the term "improvise" - "improvise" - many musicians often use the expressions "adlib", "ride" or "jam", which means creating music in the game. The vast majority of jazz pieces created spontaneously. They are not fixed in notes and are not rehearsed beforehand. As a result, the maximum of novelty. Part of the specifics of jazz is primarily related to the spontaneity of improvisation.

Analyzing the scientific literature, we came to the conclusion that a characteristic feature of improvisation is the coincidence in the time of the creation and reproduction of the creative idea. It is in this, in introducing the element of chance into an ordered type of activity, that the very idea of improvisation lies. It is no accident that at all times improvisation was seen as the highest manifestation of the creative abilities of musicians, artists, dancers, poets, actors, orators, and athletes.

Without improvisation, there is no jazz. Therefore, not all vocalists undertake jazz compositions. The jazz vocalist needs a comprehensive knowledge of jazz harmony and improvisation in order to be able to improvise professionally. A jazz performer needs to have in his stock various rhythmic harmonic and melodic patterns (blanks). After understanding and letting all this knowledge through, the jazz performer can apply them individually. According to the degree of freedom and preparedness, improvisational solos are divided into four types. Quasiimprovisation - completely created in a rational way, learned by heart, and performed (L. Armstrong, O. Peterson, D. Brubeck). Improvisation is composed in a rational way, learned by heart, but the musician makes small deviations from the text (C. Parker, F. Novarro). Improvisation has prepared pieces (culmination, breaks, complex sequences), but the musician in the process of performance can on the move replace them with new ones (C. Parker, K. Brown, 
M. Davis). Improvisation is spontaneous from beginning to end. There is not a single prepared fragment (late J. Coltrane, O. Coleman, M. Davis, and others) $[9,59]$.

In the jazz performance, the personality of the musician as the bearer of synthetic creativity and the interpreter of artistic information comes to the fore, therefore this type of creator contains the qualities of both the composer and the performer. The jazz vocalist is not limited to the music text and instructions of the composer, the singer himself is the author in a certain sense. Since in the creation of improvisation the design and its implementation are carried out at a time, it means that it is determined directly by the creative process itself $[8,184]$.

In our opinion, when investigating the relationship between interpretation and improvisation, one should emphasize that jazz vocals are determined directly by the individual qualities of the singer. Analyzing jazz art, we come to the conclusion that jazz improvisation in its «classical» form is a free artistic interpretation of the image of the original theme that corresponds to the interpretation of personal musical ideas. (The individual characteristics of the jazz performer are determined by artistic and expressive means.) Articulation, dynamics, nuance, jazz manner of performance, characteristic vocal timbres, melismatics, agogyka, phrasing, and a sense of rhythm among them.

It is necessary to refer to the text and its interpretation in order to trace the interrelation of improvisation and interpretation in the performing arts of jazz vocalists. The note text of academic music differs from the musical text, which is intended for jazz performers. It is enough to open a well-known collection of jazz themes "Realbooks" and the jazzman at once everything will become clear and, on the contrary, many things will be incomprehensible for a musician unprepared for such decoding of a musical text. The musical text of jazz music is the basis, which only in the process of execution turns into a genuine musical work in the generally accepted sense of the word. Signed music notation takes the form of instruction for the subsequent audio interpretation of the performer. Penetration into the «spirit» of the age, the finding of kinship ties in related art - this kind of musical text opens up a wide field of activity for the performer, provides him with creative freedom for self-expression, opens the possibility for the performer to choose a variety of harmonic, rhythmic and melodic means, which directly to the full manifests itself in the improvisation of the performer.
Each element of the music text - a musical notation, a verbal or graphic designation - by virtue of its semiotic nature can be deciphered within a certain field of values. Therefore, when decoding the notation text, the performer makes a choice every time from a number of possible readings, in other words, interprets this text [5]. Thus, decoding is inseparable from interpretation. The task of the performer at the present stage combines two antagonistic components: the requirement to be extremely adequate and accurate when reproducing the composer's intention and the need to identify one's own identity in its interpretation.

Work on creating their own interpretation contributes to the formation of a value and creative attitude to the work, motivates work on its performance (technical) and theoretical (cultural-historical) development. Thus, the interpretation allows us to reveal the individual abilities of the musician: maximizes his independence in solving creative problems of interpretation. Develops intellectual, motivational and emotional spheres, musical erudition and taste, attracting life and aesthetic experience. All this creates an amazing complex of processes and results of creativity, interpretation, and perception.

Conclusions. We conclude that the interaction of interpretation and improvisation is clearly traced since interpretation is an aspect of musical practice that results from the differences between the recorded music notation and the live performance of the work. Therefore, it can be argued that this process inherent element of unpredictability. The interrelation between the interpretation of the notation text and the mastery of the improvisation demonstration of this text by the interpreter is traced, which is determined directly by his individual qualities.

\section{References}

1. Aggeeva N. M. (2011). From interpretation to improvisation. Art and education. No. 2. [in Russian].

2. Asafiev B.V. (1978). Concert guide - 2nd ed., Add. Moscow: Music [in Russian].

3. Batashev A. N. (1987). The phenomenon of improvisation. Moscow: Music [in Russian].

4. Barenboim L. A. (1974). Musical pedagogy and performance. Leningrad: Music [in Russian].

5. Gmyrina S. V. On the problem of interpreting a piece of music in vocal performance. Access mode: http//:elibrari.kubg.edu.ua [in Russian].

6. Grove. Music Dictionary (2001). Moskow: Praktika [in Russian].

7. Davydov S. (2001). On the question of interpreting the texts of jazz music. Text for musical creation: practice and theory. Kyiv [in Russian]. 
8. Keldysh Yu. V. (2008). Musical encyclopedia. Moskow: Ed. House "Gorodets" [in Russian].

9. Korolev O.K. (n.d.). Encyclopedic dictionary of jazz, rock and pop music: terms and concepts. Moscow: Music [in Russian].

10. Medushevsky V.V. (n.d.). Intonational form of music. Moskow: Composer [in Russian]

11. Ocheretovska N. L. (n.d.). Ukrainian vocabulary of musical terms. Kharkiv: Athos [in Russian].

12. Ovcharov I.V. (2010). The role and place of improvisation in the educational process of universities of culture and arts. Volgograd [in Russian].

13. Saponov M. A. (1982). Art of improvisation: Improvisational types of creativity in Western European music of the Middle Ages and Renaissance. Moscow: Music [in Russian].

14. Yutsevich Yu. E. (1988). Dictionary of musical terms. Kyiv: Muz. Ukraine [in Russian].

\section{Jimepamypa}

1. Аггеева Н. М. От интерпретации к импровизации: Искусство и образование №2, 2011. C. $104-115$.

2. Асафьев Б.В. Путеводитель по концертам. 2-е изд.: М. : Музыка, 1978. 200 с.

3. Баташев А. Н. Феномен импровизации: М.: Сов. Музыка, 1987. С. 46 - 49.

4. Баренбойм Л. А. Музыкальная педагогика и исполнительство: Л.: Музыка, 1974. 336 с.
5. Гмырина С. В. К проблеме интерпретации музыкального произведения в вокальноисполнительском искусстве URL: http://elibrari.kubg.edu.ua/3515/1/Gmirina\% 20S.PDF (дата звернення: грудень 2020).

6. Гроув. Музыкальный словарь: М. : Практика, 2001. 1095 с.

7. Давыдов С. К вопросу об интерпретации текстов джазовой музыки: Київ, 2001. С. 180-191.

8. Келдыш Ю. В. Музыкальная энциклопедия: М. : Изд. Дом «Городец», 2008. $264 \mathrm{c}$.

9. Королев О. К. Энциклопедический словарь джаза, рок и поп-музыки: М. : Музыка, 2002. 166 с.

10. Медушевский В. В. Интонационная форма музыки: М. : Композитор, 1993. 265 с.

11. Очеретовська Н. Л. Український словник музичних термінів: Харків: Атос, 2008. 178 с.

12. Овчаров И. В. Роль и место импровизации в учебно-образовательном процессе вузов культуры и искусств (на материале работы кафедры эстрадно-джазового искусства): Изв. Волгогр. гос. пед. ун-та. 2010. №9. С. 47-49.

14. Сапонов М. А. Искусство импровизации: М.: Музыка, 1982. 77 с.

15. Юцевич Ю. Е. Словарь музыкальных терминов: Киев: Муз. Україна, 1988. 263 с.

Стаття надійшла до редакиії 20.01.2021

Отримано після доопраџювання 04.02.2021 Прийнято до друку 08.02.2021 